\title{
Ukrainian Folk Prose: Survey of Modern Social Actuals
}

\author{
Natalya Melnik ${ }^{1, *}$ \\ ${ }^{1}$ Kryvyi Rih State Pedagogical University, Ukraine \\ *Corresponding author.Email: melniknatalya1906@gmail.com
}

\begin{abstract}
The paper discusses problems of modern operation of social jokes as short prose genres that swiftly reacts to nowadays events. It has been estimated that compact form of information delivery peculiar to funny story has become the most productive amongst other samples of the form. The spotlight is given to necessity of social approach usage while analysing the newest folk texts. The approach foresees study of folk examples from the viewpoint of their social contents. On a par with musically-poetic compositions about coronavirus and its impact on social life a range of prosaic compositions has recently emerged. Considerable place amongst these compositions belongs to a phenomenon of a funny story. It is a layer of family and social compositions which in spite of serious danger of coronavirus infection, psychological and physical discomfort felt by a person while pandemic is a manifestation of optimistic worldview and evidence of normal development of a nation. We have separated out the commonest genre-thematic types of prose new compositions, that appeared during world pandemic (funny dialogs about quarantine, funny stories in a format of mass media news, ironic thoughts with diagnostics of modern problems, funny advises, funny announcements); we have also sorted out common functions of jokes in modern social problems. Compositions are regarded as a result of processing modern problems with folklore awareness; examples that not only present actuals of modern life from a national joking culture position but contain ironic analysis of queries with historical content; ideological, economic, moral and ethic condition of society and evidence about deep understanding of urgent problems of social life by the people. Active functioning of a funny story in modern conditions is an evidence of optimistic worldview of Ukrainian people and ability of nation to healthy self-irony. It has been estimated that authors new compositions quite swiftly obtain folkloric traits and are an enriching source for traditional folklore.
\end{abstract}

Key words: folklore, folk prose, funny story, folklorization.

\section{1. ВСТУП}

Виходячи 3 розуміння фольклору як визначальної складової традиційної культури, універсального засобу вираження національної ментальності, що $є$ важливим чинником формування «духовного світу особистості, < ..> iii психологічної самодостатності й комфорту», завдання його вивчення набуває особливого значення [3, 5].

Нині дослідження фольклору має спиратися не лише на теоретичні концепції минулого, але й ураховувати можливості «<..> синтезу професійних знань і нових методологічних підходів». Особливо це важливо, коли «йдеться про сутнісні характеристики явищ специфічної форми суспільної свідомості <..>» $[3,5]$.

Фольклористика останніх десятиліть, враховуючи специфіку «нових громадськополітичних, культурних умов співдії індивіда і колективу та шляхів реалізації фольклорного i нефольклорного мислення» звертається до проблем фольклоризму, фольклоризації та нефольклорного мислення [5, 11].

\section{2. ВЕКТОР НАУКОВИХ ПОШУКІВ}

Сьогодні у колі зацікавлень сучасної фольклористики - не лише давні, але й нові пласти народної творчості [3, с. 5]. Нині світова наука про фольклор рухається в антропоцентичному напрямі, що спирається на «спостереження 
спонтанного функціонування усного тексту та врахування виконавської природи фольклору» [1]. Трендовим напрямом світової науки про фольклор сьогодні є «балансування на межі фольклористики і соціології» (М. Дмитренко), «тенденція розгляду фольклору в соціополітичному дискурсі» (І. Головаха-Гікс) $[2,9]$.

На думку М. Дмитренка, нині спеціального фольклористичного дослідження потребує проблема національних, регіональних, соціологічних чинників у жанрології [3].

До вивчення народної прози зверталися у своїх працях О. Бріцина, Р. Кирчів, О. Кузьменко, С. Мишанич, І. Павленко, В. Сокіл.

Аналізуючи провідні тенденції дослідження народної прози, у студії «Біля джерел народної прози» С. Мишанич окреслює два основні напрямки їі вивчення: фольклористичний (вивчає феномен фольклорності, розглядає твори у системі жанрів тощо) та соціологічний (специфіка матеріалу якого, полягає у «відбитті сьогочасного життя») $[10,306]$. Саме соціологічний підхід, на нашу думку, дозволяє діагностувати сучасний стан функціонування фольклору, зафіксувати власне момент його творення як реакції на життя суспільства.

Особливо продуктивним у цьому смислі, на нашу думку, є пласт народної прози, яка живо реагує на події сучасності. Ми погоджуємося 3 твердженням О. Кузьменко, яка вважає, що «аналіз сучасних меморатів і фабулатів $<\ldots>-$ це ключ до розуміння національного світобачення та втіленої в образне слово народної шкали цінностей» [6, 258]. Дослідження народної прози, як зазначає А. Карбан, сприяє «осмисленню істотних закономірностей фольклорної системи <..> 3 позицій жанрової специфіки новотворів <..> та «актуалізує важливі соціальні, когнітивні та ідеологічні функції у створенні й трансмісії усних текстів про значимі суспільні процеси і явища», що $\epsilon$ актуальними проблемами сучасної фольклористики $[4,4]$.

У праці «Двадцяте століття в українському фольклорі» (2010) Р. Кирчів акцентує на життєздатності та функціональності, починаючи 3 минулого століття, малих фольклорних форм i жанрів (коломийок, частушок, приспівок до танцю («приказусів»), шумок, чабарашок, співомовок, віршиків, епіграм, загадок, приказок, каламбурів, абревіальних формул), особливу роль відводячи анекдоту. Дослідник вважає, що анекдот як «найбільш мобільний і впливовий вид народної творчості», завдяки своїй здатності «оперативно відгукуватися і сміливо реагувати на болючі й актуальні суспільні справи», виходить у XX столітті на перше місце [9, 520]. На думку науковця, це свідчить про соціалізацію та політизацію народної творчості: «анекдот і низка інших малих форм усної народної творчості піднялися в новітню добу до рівня політичної сатири» $[9,520]$.

I. Кімакович у дослідженні «Традиційний анекдот у контексті сміхових явищ української культури» (1997) висловлює думку про те, що сучасну культуру загалом можна кваліфікувати як сміхову, оскільки «суб'єкт у процесі споглядання об'єкта та усвідомлення його властивостей як безглуздих чи незрозумілих відчуває подив i відчуття власної переваги. Ці почуття й породжують оціночний <...> сміх як відгук на певну потворну даність (предмет, дію, ідею)», що $\epsilon$ «реакцією індивідуальною, проте на нього завжди впливають суспільні цінності» $[7,6,10]$.

У студії «Ізоморфізм фольклорних жанрів» I. Кімакович зазначає, що, хоча анекдот має всі ознаки окремого фольклорного жанру, його часто «розглядають у сфері усної народної казкової прози, співвідносячи анекдот із побутовою (соціально-побутовою) казкою <..> Дійсно, в процесі реального функціонування сміхової традиції межа між казкою та анекдотом часом $\epsilon$ досить умовною, і в цьому, зокрема, й виявляється системний зв'язок анекдоту 3 іншими виявами сміхової традиції» [8]. Також дослідниця вказує на близькість анекдоту до народного оповідання, підкреслюючи, що обидва жанри $є$ формами відображення духовної культури, світогляду народу; функціонують у межах оповідальної традиції. Відмінність полягає у тому, що «усне оповідання - це індивідуальний усний текст, хоча й використовує засоби та прийоми, вироблені традицією, а анекдот - це текст традиційний (колективний), який, хоча й засвідчує індивідуальну манеру передачі оповідача, все ж таки не має автора і $є$ «загальним» знанням певної аудиторії» [8]. (курсив наш - Н. М.).

Чимало спільних рис має анекдот із жанрами неказкової прози, зокрема, прислів'ями, народними оповіданнями, легендами та переказами. До прислів'я анекдот наближають двоплановість змісту та коротка форма викладу. Проте, на думку науковців, анекдот не можна вважати афоризмом. Це скоріше «лаконічне оповідання 3 кульмінаційним моментом, який повинен породжувати сміхову реакцію» [8]. Від 
народних оповідань, легенд, переказів анекдот відрізняє відсутність у змісті конкретизації, високий рівень узагальнення, здатність відображати переважно щоденні ситуації. На відміну від усного народного оповідання, анекдот завжди сприймається як інформація про реальні факти: «Достовірність анекдоту детермінується ситуаціями, в яких він побутує. Анекдот 3'являється таким, де треба об'єктивно переконати, і таким чином навіть анекдот-вигадка сприймається як достовірний факт» [8].

На думку I. Кімакович, анекдот у системі жанрів слід розглядати не як «<..> самостійний художній твір, закінчене митецьке явище, образна система й ідеї якого акумульовані в самій художній сутності його тексту», а у зв'язках 3 іншими творами казкової та неказкової прози, оскільки «<..> комунікативні контексти, в яких функціонують сміхові твори, здебільше й визначають їхні змістові, художні та функціональні характеристики» [8].

У процесі аналізу особливостей жанру, дослідниця спостерегла, що в основі змісту анекдоту повинен лежати оригінальний сюжет, який буде прийнятий народною традицією за наявності таких умов: «По-перше, потрібно, щоби зафіксовані в сюжетах явища та життєві узагальнення були цікавими для широкого кола слухачів за різних обставин: з'ява сюжетів зумовлюється їхньою актуальністю. I по-друге, такий сюжет має бути здатним до трансформацій, щораз пристосовуючись до нової життєвої реальності: популярність зумовлюється комунікативною спроможністю» [7, 17]. Науковець відзначає також здатність анекдоту варіюватися в залежності від комунікативних ситуацій та «принципову установку носіїв на варіювання текстів» що продиктовано особливостями його усного побутування [8].

У процесі аналізу поетики анекдоту як мобільного жанру, що видозмінюється в повсякденному спілкуванні, слід ураховувати «суб'єктний фон» під час виконання твору; статуси виконавця (адресанта) та слухача (адресата); характер їхніх стосунків, особистісні ознаки (вік, стать, освіту, місце проживання, темперамент, обсяг інформації, вміння імпровізувати), оскільки від цього залежать змістові та формальні показники традиційного твору в конкретній функціональній ситуації [8].

Важливою умовою виконання анекдоту наявність відповідної довірливої атмосфери між виконавцем та слухачем (слухачами), оскільки тоді «відкидаються всі табу, що обмежують тематику й саму форму комунікації. Саме тому анекдот дуже часто відносять до сфери «антикультури» < ..> орієнтація на офіційний чи неофіційний тип спілкування впливає на відбір тематики текстів, їхнє лексичне відтворення та на сукупність позатекстових елементів. На різноманітних приватних зібраннях, метою яких $\epsilon$ розваги, відбувається пряма i асоціативна циклізація текстів. За таких умов кожен твір $є$ ланкою «ланцюга розмови»: спровокований попереднім, він зумовлює наступний і фактично виконує роль репліки в полілозі» [8].

\section{3. ПРЕЗЕНТАЦІЯ ОСНОВНОГО МАТЕРІАЛУ ДОСЛІДЖЕННЯ}

Анекдот - малий прозовий жанр, який займає проміжну ланку між казковою та неказковою прозою, репертуар якого складається як із вигаданих оповідань, так і 3 оповідань, породжених дійсністю [7, 76]. У первісному значенні анекдот - це побутовий меморат, що «передавав власні спогади оповідача про події, свідком яких він був» $[7,65]$. Згодом цей термін почав використовуватися в значенні коротких розповідей про «вигадані, цікаві факти» [7, 74].

Традиційні анекдоти «консервують» ментальні стереотипи, і для них гарантовано наповнення новим змістом та побутування в нових умовах» [7, 139]. Лаконічна форма викладу інформації, притаманна анекдоту, стала серед інших зразків форми найпродуктивнішою.

Ситуація світової пандемії, що охопила й українське суспільство, відбилася й на фольклорній свідомості українця. Поряд із музично-поетичними творами (коломийками, колядками, піснями) про коронавірус та його вплив на суспільне життя (соціальні обмеження, необхідність дистанційного навчання та спілкування), з'явилося чимало прозових творів, серед яких чільне місце належить анекдоту.

Це пласт родинно-побутових та соціальнопобутових творів, які, попри серйозність небезпеки коронавірусної інфекції, психологічний та фізичний дискомфорт, що його відчуває людина під час пандемії, $є$ виявом оптимістичного світобачення та свідченням нормального розвитку нації.

Найбільшого поширення в сучасних умовах набули такі жанрово-тематичні різновиди анекдотів: анекдотичні діалоги про карантин, анекдоти у форматі новин засобів масової 
інформації, іронічні сентенції 3 діагностикою суспільних проблем, анекдотичні поради, анекдотичні оголошення.

\section{Анекдотичні діалоги про карантин}

1.

- Куме, як ви проводите з дружиною вихідні?

- Як плоскогубиі!..

- Це як?

- А так. Перекусили і далі собі лежимо...

2.

В метро.

- Кхе-кхе-кахи.

- Чоловіче, Ви кашляєте, у Вас короновірус!

- Спокійно! У мене відкрита форма туберкульозу!

\section{- Хух. Слава Богу [11].}

Поява наведених зразків є результатом обробки фольклорною свідомістю проблем вимушеної ізоляції, що обмежує можливості активної діяльності, та наслідків маніпуляцій суспільною думкою українців. Цей різновид традиційного анекдоту свідчить про умовність родових та жанрових характеристик фольклорного твору: такі зразки перебувають на межі епосу та драми. Діалог побудований на певному розподілі тексту за ролями. Попри невизначеність дійових осіб (у таких творах нерідко наводяться характеристики, що дозволяють ідентифікувати учасників діалогу), анекдотичні діалоги мають яскраво виражені драматичні елементи.

Анекдоти у форматі новин засобів масової інформації також не лише констатують факти. Як правило, вони містять у собі іронічний аналіз питань історичного змісту; ідеологічного, економічного, морально-етичного стану суспільства і свідчать про глибоке розуміння народом нагальних проблем суспільного життя.

1. У Радянському Союзі ніяких короновірусів не було... Люди жили, поки їх не розстріляють [11].

2. Коронавірус терміново покидає Украӥну. Він не може жити в таких умовах, у яких живуть україниі [13].

3. Василь завів собі файну коханку. На радостях взяв $і$ розповів усе жінці. Причина смерті - коронавірус. (щодо того, щчо під коронавірус списували чимало інших причин смерті) [12].

4. 3 а останніми науковими даними, в ход $i$ вакциначії від коронавірусу людям буде вживлятися не тільки чіп, але й Дейл. Особливо небезпечним особам ще цे Гаєчка. Будьте обережні [12].

5. Після третього протирання айфона спиртом, Siri попросила сала 3 хлібом та квашеного огірка [13].

6. Викладачку так затягло дистанційне навчання, щзо тепер чоловікові борщ вона показує через Moodle [13].

Іронічні сентенції 3 діагностикою суспільних проблем $\epsilon$ результатом осмислення нагальних питань сучасного буття українця через категорію іронічного. Іронія завжди передбачає особливу позицію іронізуючого, яка свідчить про його вміння піднятися над існуючими вадами суспільства, сформувати здоровий, адекватний погляд на реальність, позбавлений ідеологічних маркерів та результатів маніпуляції особистості, суспільної свідомості через засоби масової інформації. У ракурсі народного осмислення соціальні проблеми, які пов'язані з усвідомленням життєвої значимості економічних, педагогічних, психологічних чинників:

1. Тепер можна говорити, щуо ти не поӥхав у відпустку на закордонний курорт через коронавірус, а не тому, шо немає грошей [13].

2. Величезна подяка нашому уряду. Якби не моя злиденна зарплата, я би зараз могла опинитися в Китаї, Італії чи Іспанї [13].

3. Дякую всім, хто скупив в магазині продукти, які залежалися. Такої свіжої сьомги з магазину, як учора, я щее не пробувала [14].

4. Якщео школи будуть закриті довго, то батьки знайдуть вакцину від вірусу набагато раніме, ніж вчені [14].

5. Третій день карантину. Випадково розговорився з дружиною: дуже навіть нічого жіночка виявилася [15].

Анекдотичні поради - один із різновидів традиційного анекдоту, поява якого свідчить про адаптацію прозових фольклорних жанрів до соціальних замовлень сучасності. Такі твори не передбачають об'ємної сюжетики: у короткій пораді міститься закодований діагноз суспільних проблем, викладений із урахуванням сучасних вимог до обсягу тексту, що розрахований на активне слухання. Також важливим $є$ стиль 
оповіді: це коротка порада, що грунтується на власному життєвому досвіді виконавця:

Кредити поки не виплачуйте. Будуть дзвонити - просто каиляйте [11].

Анекдотичні оголошення - сучасний різновид анекдоту, побудований за зразком інформаційного повідомлення на якусь важливу тему, що адресоване певному колу зацікавлених слухачів. Застосовуючи формальні характеристики традиційного оголошення, носій фольклору наповнює такий твір певним іронічним підтекстом, зрозумілим лише слухачевіадресатові, котрий перебуває в тих же, що i виконавець, суспільних умовах:

Руки треба мити не 20 секунд, а 20 хвилин.

(Міськводопостачання) [13].

\section{4. ВИСНОВКИ}

Узагальнивши результати нашого дослідження, можемо зробити такі висновки:

1. У процесі аналізу сучасних фольклорних новотворів найпродуктивнішим $є$ соціологічний підхід, який передбачає вивчення народних зразків із погляду їх соціального змісту.

2. Наймобільнішим, найбільш функціональним у сучасних умовах виявився такий жанр неказкової прози як анекдот. Основною його перевагою відносно інших жанрів є лаконічність та здатність швидко реагувати на злободенні суспільні проблеми.

3. Найбільшого поширення в сучасних умовах набули такі жанрово-тематичні різновиди анекдотів: анекдотичні діалоги про карантин, анекдоти у форматі засобів масової інформації, іронічні сентенції 3 діагностикою суспільних проблем, анекдотичні поради, анекдотичні оголошення.

Анекдотичні діалоги класифіковано як твори, що перебувають на межі епосу та драми і свідчать про здатність фольклорної свідомості до змістових, та формальних трансформацій відповідно до потреб часу. Такі твори, попри епічну природу, мають яскраво виражені ознаки драми.

Анекдоти у форматі новин засобів масової інформації - твори, які, поряд із констатацією фактів, містять у собі глибокий іронічний аналіз питань історичного змісту; ідеологічного, економічного, морально-етичного стану суспільства і свідчать про глибоке розуміння народом нагальних проблем суспільного життя.

Іронічні сентенції з діагностикою суспільних проблем класифіковано як твори, що є результатом осмислення економічних, психологічних, педагогічних питань сучасного буття українця крізь призму іронічного. Такі зразки позбавлені ідеологічних маркерів та свідчать про здатність народу протистояти маніпуляціям суспільною свідомістю, об'єктивне сприйняття реальної дійсності.

Анекдотичні поради визначено як один із різновидів традиційного анекдоту, що ілюструє здатність фольклорної свідомості адаптуватися соціальних потреб сьогодення. У короткій формі вміщено закодований об'єктивний діагноз суспільних негараздів, викладений із урахуванням сучасних вимог до обсягу тексту, що розрахований на активне слухання. Також важливим є стиль оповіді: це коротка порада, що грунтується на власному життєвому досвіді виконавця.

Анекдотичні оголошення класифіковано як різновид анекдоту - інформаційне повідомлення. Важливою ознакою таких творів $є$ іронічний підтекст, зрозумілий слухачеві не лише як носієві культурної традиції, але й реципієнтові, котрий, відповідно до сучасних тенденцій розвитку суспільства, прагне отримати змістовну та лаконічну інформацію із важливої для нього теми.

4. Авторські новотвори досить швидко набувають рис фольклоризації i $\epsilon$ джерелом збагачення традиційного фольклору.

\section{ВНЕСОК АВТОРА}

У запропонованій праці висвітлені проблеми сучасного функціонування соціально-побутового анекдоту як малого прозового жанру, який швидко реагує на події сьогодення. Визначено, що лаконічна форма викладу інформації, притаманна анекдоту, стала серед інших зразків форми найпродуктивнішою щодо сучасних суспільних потреб.

Акцентовано на необхідності застосування соціологічного підходу в процесі аналізу новітніх фольклорних текстів, який передбачає вивчення народних зразків із погляду їх соціального змісту.

3'ясовано, що поряд із музично-поетичними творами про коронавірус та його вплив на суспільне життя, нині з'явилося чимало прозових творів, серед яких чільне місце належить анекдоту. Відзначено, що цей пласт родинно-побутових та 
соціально-побутових творів, які, попри серйозність небезпеки коронавірусної інфекції, психологічний та фізичний дискомфорт, що його відчуває людина під час пандемії, $є$ виявом оптимістичного світобачення та свідченням психологічного здоров'я української нації.

Окреслено найпоширеніші жанрово-тематичні різновиди прозових новотворів, що виникли в ситуації світової пандемії (анекдотичні діалоги про карантин, анекдоти у форматі новин засобів масової інформації, іронічні сентенції 3 діагностикою суспільних проблем, анекдотичні поради, анекдотичні оголошення); окреслено суспільні функції анекдоту в сучасних умовах. Твори осмислено як результат обробки фольклорною свідомістю сучасних суспільних проблем; зразки, які не лише презентують реалії сучасного життя $з$ позицій національної сміхової культури, але й містять у собі іронічний аналіз питань історичного змісту; ідеологічного, економічного, морально-етичного стану суспільства і свідчать про глибоке розуміння народом нагальних проблем суспільного життя.

Активне функціонування анекдоту в сучасних умовах є свідченням оптимістичного світобачення українців та здатності нації до здорової самоіронії.

Спостережено, що авторські новотвори досить швидко набувають рис фольклоризації і $\epsilon$ джерелом збагачення традиційного фольклору.

\section{REFERENCES}

[1] O. Britsyna, Do pytannia pro metodolohichni zasady naukovoho zbyrannia folkloru: narodna proza, 2013. https://philology.lnu.edu.ua/wpcontent/uploads/2016/12/Rodyna_Kolessiv_Bric yna_O_Do_pytannya_2013.pdf

[2] I. Holovakha-Khiks, Na mezhi sotsiolohii i folklorystyky: rol «Pervisnoho hromadianstva» Kateryny Hrushevskoi v rozvytku sotsiohumanitarnoi nauky v Ukraini, Sotsiolohiia: teoriia, metody, marketynh (4) (2011) 177-186.

[3] M. Dmytrenko, Folklor: katehoriia zhanru (krytyko-analitychnyi ohliad), in: M. K. Dmytrenko (Ed.), Ukrainskyi folklor: metodolohiia doslidzhennia, dynamika funktsionuvannia, PALYVLODA, Kyiv, 2014, pp. 9-21.

[4] A.A. Karban, Dynamika epichnoi tradytsii v narodnii prozi pro holodomor 1932-1933, dys. ... kand. filol. nauk: 10.01.07, Kyiv, 2017, 200 p. https://shron1.chtyvo.org.ua/Karban_Alina/Dyn amika_epichnoi_tradytsii_v_narodnii_prozi_pro _holodomor_1932-1933_rr.pdf.

[5] O. Kuzmenko, Striletska pisennist: folkloryzm, folkloryzatsiia, folklornist, Instytut narodoznavstva NAN Ukrainy, Lviv, 2009, $296 \mathrm{p}$.

[6] O. Kuzmenko, Striletska tema v narodnii prozi pro pershu svitovu viinu (abo motyvy mynuloho $\mathrm{u}$ vyklykakh novoi doby), in: $\mathrm{Z}$ istorii zakhidnoukrainskykh zemel, iss, 10-11, Lviv, 2015, pp. 257-277.

[7] I.I. Kimakovych, Tradytsiini anekdot u konteksti smikhovykh yavyshch ukrainskoi kultury, dys. ... kand. filol. nauk: 10.01.07, NAN Ukrainy, Instytut mystetstvoznavstva, folklorystyky ta etnolohii im. M. T. Rylskoho, Kyiv, 1996, 248 p.

[8] I. Kimakovych, Izomorfizm folklornykh zhanriv, 2017. https://tinyurl.com/6bp2ryub

[9] R. Kyrchiv, Dvadtsiate stolittia v ukrainskomu folklori, Instytut narodoznavstva NAN Ukrainy, Lviv, 2010, 536 p.

[10] S. Myshanych, Bilia dzherel narodnoi prozy, in: Folklorystychni ta literaturoznavchi pratsi: u 2 t., vol. 1, DNU, Donetsk, 2003, pp. 311-312.

[11] Smikh - krashchi liky: u merezhi publikuiut anekdoty ta karykatury pro koronavirus, 2020. https://glavcom.ua/country/society/smihkrashchi-liki-u-merezhi-publikuyut-anekdoti-takarikaturi-pro-koronavirus-665691.html

[12] M. K. Dmytrenko (Ed.), Ukrainskyi folklor: metodolohiia doslidzhennia, dynamika funktsionuvannia, PALYVLODA, Kyiv, 2014, $252 \mathrm{p}$.

[13] Anekdoty pro koronavirus, 2020. http://www.niknews.mk.ua/2020/04/11/anekdot y-pro-koronavirus/

[14] D. Koberska, Naikrashchi zharty pro koronavirus do Dnia smikhu - chastyna druha, 2020. https://iod.media/article/pidbirka-naykrashchihzhartiv-pro-koronavirus-na-chest-1-kvitnya5395

[15] A. Paskevych, 10 anekdotiv pro koronavirus, nad yakymy smiiutsia ukraintsi, 2020. https://www.obozrevatel.com/ukr/lady/holidays/ 10-anekdotiv-pro-koronavirus-nad-yakimismiyutsya-ukraintsi.htm 